\title{
Hatch-Waxman Patent Case Settlements- The Supreme Court Churns the Swamp
}

\author{
Kent Bernard*
}

\section{INTRODUCTION}

To lusty cheers of consulting economists and litigating lawyers everywhere, and the heartfelt groans of everyone responsible for litigation budgets at pharmaceutical companies, the Supreme Court in FTC v. Actavis, Inc. ${ }^{1}$ rejected both (a) the settling parties' view that any settlement within the scope of the patent at issue and not the result of sham litigation was legal;2 and (b) the FTC's view that any settlement which involved a transfer of any money or asset from the patent owner to the challenger was presumptively illegal. ${ }^{3}$ The Court chose to open up door (c), and require that there be a full "rule of reason" inquiry into the settlement. ${ }^{4}$ Those who were afraid that the Court might actually settle the law here can breathe easily again.

In the underlying litigation, Solvay settled infringement suits with would-be generic producers with a settlement which let the generics enter on a date certain (before the expiration of the patent at issue), and with payments to the alleged infringer in exchange for the performance of certain marketing and promotional services for Solvay. ${ }^{5}$ The FTC alleged that these services had little value and that the payments were really made to compensate the generics for agreeing to delay their entry into the market. ${ }^{6}$

\footnotetext{
(C) 2014 Kent Bernard

* Adjunct Professor, Fordham University School of Law, JD 1975 University of Pennsylvania; BA 1972 Colgate University.

1. FTC v. Actavis, Inc., 133 S. Ct. 2223 (2013).

2. Id. at 2237 .

3. $I d$.

4. Id. at 2237-38.

5. Id. at 2229 .

6. Id. at $2229-30$.
} 
The district court dismissed the FTC's complaint under the "scope of the patent" test, and the Eleventh Circuit affirmed, holding that "absent sham litigation or fraud in obtaining the patent, a reverse payment settlement is immune from antitrust attack so long as its anticompetitive effects fall within the scope of the exclusionary potential of the patent."

Some ninety-five percent of all patent cases are resolved by settlement before a court judgment. ${ }^{8}$ Settlements are not only permitted, but favored. There is not, and rationally cannot be, any requirement that every case needs to be litigated to the death. Only someone who has either never litigated, or never worried about a litigation budget, would suggest a "no settlements" rule. The question comes down to what limits, if any, the law imposes on the parties' freedom to settle the cases. And does the fact that cases arose under the provisions of the Hatch-Waxman Act ${ }^{9}$ make any difference?

The Supreme Court had essentially four possible ways to deal with these issues:

A. The Scope of the Patent Test: This was the majority rule, which held that if the settlement was within the scope of the patent and the litigation was not sham, the decision of the parties as to the terms of settlement would be respected. ${ }^{10}$ This is the rule applied to patent cases in general, and the question was whether it should also apply in the somewhat weird world of Hatch-Waxman (more on this below).

B. The Presumptive Illegality Test: This was the FTC's approach, and a slight retreat from its initial position. To the

7. FTC v. Watson Pharm., Inc., 677 F.3d 1298, 1312 (11th Cir. 2012), rev'd sub nom. FTC v. Actavis, Inc., 133 S. Ct. 2223 (2013).

8. Marc G. Schildkraut, Patent-Splitting Settlements and the Reverse Payment Fallacy, 71 ANTITRUST L.J. 1033, 1048 (2004).

9. Drug Price Competition and Patent Term Restoration (HatchWaxman) Act of 1984, Pub. L. No. 98-417, 98 Stat. 1585 (codified as amended in scattered sections of $15,21,28$, and 35 U.S.C.). While the statute is usually cited as encouraging generic drugs, it also attempted to help restore the patent life lost in the regulatory review process. See H.R. REP. No. 98-857, pt. 1, at 15 (1984) (describing how Title II of the Act incentivized research and development through "restoration of some of the time lost on patent life while the product is awaiting pre-market approval"). The intent was to provide something for the generics and something for the innovators. That second part tends to be overlooked.

10. Actavis, 133 S. Ct. at 2239 (Roberts, C.J., dissenting) ("[T]he patent holder-when doing anything, including settling — must act within the scope of the patent."). 
FTC, a settlement is legal if the patent owner gives up one kind of property (part of his patent term), but presumptively illegal if he gives up some other kind of property (such as a cash payment). The original formulation of the test was that any payment or transfer of value of any kind (other than giving up part of the patent tem) was not merely presumptively, but per se illegal (and the FTC urged Congress to so legislate). ${ }^{11}$ But before the Court in Actavis, the FTC scaled back to requesting only that the settlement be presumed to be illegal and that the parties could try to justify it ${ }^{12}$ - to the same agency that had publicly announced many times that such settlements were all illegal.

C. The Rule of Reason Test: The full, untrammeled rule of reason inquiry: whether, on balance, the pro-competitive aspects of the transaction outweigh the anticompetitive aspects. ${ }^{13}$ As this is the test that the Court adopted, we will speak about it in more depth below.

D. Let Congress Fix What Congress Hath Wrought: This argument is really quite simple. What prompted the whole situation of odd-looking settlements was the structure that Congress set up in the Hatch-Waxman Act. Under that statute, a generic company can take a patented drug, create its own version, and do the bioequivalence testing necessary to get it approved, all without being deemed to have infringed the innovator's patent. ${ }^{14}$

11. For example, in the 109th, 110th, 111th, and 112th Congresses, Senator Herb Kohl (together with between four and nine co-sponsors from both parties) introduced the Preserve Access to Affordable Generics Act. S. 27, 112th Cong. (2011); S. 369, 111th Cong. (2009); S. 316, 110th Cong. (2007); S. 3582 , 109th Cong. (2006). The proposed bills would have made it unlawful for a brand-name manufacturer and a generic ANDA filer to enter into any agreement where "(i) an ANDA filer receives anything of value," and "(ii) the ANDA filer agrees not to research, develop, manufacture, market, or sell the ANDA product for any period of time.” E.g., S. 27, 112th Cong. § 3(a) (2011). None of the proposed bills passed.

12. Actavis, 133 S. Ct. at 2237.

13. See, e.g., Cal. Dental Ass'n v. FTC, 526 U.S. 756, 779-80 (1999) ("'[W]hether the ultimate finding is the product of a presumption or actual market analysis, the essential inquiry remains the same-whether or not the challenged restraint enhances competition." (quoting Nat'l Collegiate Athletic Ass'n v. Bd. of Regents of Univ. of Okla., 468 U.S. 85, 104 n.26 (1984))).

14. See 35 U.S.C. § 271(e)(1) (2006 \& Supp. V 2011) (providing that uses of patented inventions "reasonably related to development and submission of information under a Federal Law" related to manufacture and sale of pharmaceuticals are not acts of infringement). 
Hatch-Waxman set up an artificial act of infringement (Paragraph IV filing); 15 essentially a no-risk way for a generic to provoke a challenge, putting the patent at issue. As Courts and commentators have pointed out at length, this skewed the risk/reward calculus for the parties: The infringer (generic) has no downside (litigation costs only), 16 and a huge potential upside (it may gain the entire product market-first to file, 180 day exclusivity, and mandatory generic substitution). ${ }^{17}$ The innovator has no upside (the best that it can do is preserve what it has-there are no damages to compromise as a settlement), and a huge potential downside (lose the whole product market). And as courts and commentators have repeatedly recognized, patent litigation is always a risk-there is a real chance of losing your patent even when you should win. 18

That means that a generic company with a weak or nonexistent case still has an enormous incentive to "infringe" by making the filing. The unique position that ANDA filers have in Hatch-Waxman litigation encourages Paragraph IV certifications, and persistent litigation, even where the generic has little reason to be confident regarding its prospects on the merits. ${ }^{19}$

Given that Congress set up this weird mix of incentives and disincentives, and given that what is at issue here is the balance between rewarding innovation and encouraging generic entry to lower prices, and given that this is an area in which Congress has chosen to legislate, then why not leave it up to Congress to fix the mess that it created?

15. 21 U.S.C. $\S 355(\mathrm{j})(2)(\mathrm{A})(\mathrm{vii})(\mathrm{IV})(2012)$.

16. Kelly Smith \& Jonathan Gleklen, Generic Drugmakers Will Challenge Patents Even When They Have a 97\% Chance of Losing: The FTC Report that K-Dur Ignored, 9 CPI ANTITRUST CHRON., Sept. 2012, at 6, available at https://www.competitionpolicyinternational.com/file/view/6746 ("[T]aking a shot at a patent is, if not costless, quite cheap. The only costs of a challenge are litigation expenses and the cost of regulatory approval.").

17. In re Tamixofen Citrate Antitrust Litig., 429 F.3d 370, 391 (2d Cir. 2005) ("The incentive ... may be immense: the profits [a generic] will likely garner in competing with the patent holder ... and ... possible entitlement to a 180-day period... during which it would be the exclusive seller of the generic drug in the market.").

18. See, e.g., Kent S. Bernard \& Willard K. Tom, Antitrust Treatment of Pharmaceutical Patent Settlements: The Need for Context and Fidelity to First Principles, 15 FED. CIR. B.J. 617, 627-28 (2005).

19. See generally Smith \& Gleklen, supra note 16. 


\section{WHAT THE COURT'S DECISION IN ACTAVIS ACTUALLY DID}

We will hear a lot of spinning about who "won" this case, and indeed both sides can claim the laurel. The FTC "won" because it gets to bring these challenges. The manufacturers "won" because the FTC will have to prove a full rule of reason case without any presumption that payments are illegal.

So let's look at the decision itself. The majority opinion, authored by Justice Breyer, held that antitrust challenges to reverse payment settlement agreements should be analyzed under the rule of reason. ${ }^{20}$ The Court recognized that the "scope of the patent" test was grounded on a strong policy consideration favoring settlements, and that the rule of reason would likely reduce the litigating parties' incentive to settle patent infringement suits, but agreed with the FTC that "there is reason for concern" that reverse payment settlements "have significant adverse effects on competition," and that the "scope of the patent" test therefore did not subject such agreements to a sufficient amount of antitrust scrutiny. ${ }^{21}$

However, the Court also rejected the FTC's argument that reverse payment agreements are presumptively unlawful. ${ }^{22}$ Since the dissent also rejected the FTC's argument, one of the less publicized results of the case is that the "presumption of illegality" which the FTC has been pushing was rejected by all the Justices participating in the case.

In making its determination, the Court specifically pointed to "five sets of considerations," 23 which it summarized as follows:

[A] reverse payment, where large and unjustified, can bring with it the risk of significant anticompetitive effects; one who makes such a payment may be unable to explain and to justify it; such a firm or individual may well possess market power derived from the patent; a court, by examining the size of the payment, may well be able to assess its likely anticompetitive effects along with its potential justifications without litigating the validity of the patent; and parties may well find ways to settle patent disputes without the use of reverse payments. ${ }^{24}$

20. FTC v. Actavis, Inc., 133 S. Ct. 2223, 2237 (2013).

21. Id. at 2231 .

22. Id. at 2237-38.

23. Id. at 2234-37.

24. Id. at 2237 (emphasis added). 
Like many majority opinions, this one seems to reflect compromises and comments necessary to get the majority vote. Statements that reverse payment settlements in which there are no actual damages are unusual outside the pharmaceutical field are disingenuous.

First, we don't know about most settlements. No law requires them to be filed with the FTC or made public except in the Hatch-Waxman drug field. ${ }^{25}$ Second, cases outside of the Hatch-Waxman universe are indeed sometimes settled with a combination of payments and cross-licenses, the net result of which may be a payment to the alleged infringer (when all the valuations are done). ${ }^{26}$ Third, in no field of which the author is aware, other than Hatch-Waxman cases, do you have a situation where the norm is that the infringement has not caused any actual damages at the time of trial. The artificial trigger of infringement is unique to Hatch-Waxman. Given the oddity of the statute, some oddities in the settlements could be foreseen.

The majority opinion raises some fascinating questions:

A. What kinds of settlements are now permissible? The Court states that it is permissible to negotiate a date certain for generic entry prior to the patent's expiration. ${ }^{27}$ It also states that cash payments to a generic company may be justified under certain limited circumstances, such as to compensate for litigation costs. ${ }^{28}$ And it is legal to pay fair value for services or products from the potential infringer. ${ }^{29}$

B. What kinds of settlements are now at risk? The Court repeatedly emphasizes that "[a]n unexplained large reverse payment itself" suggests that the patentee has doubts about the patent's strength and survival. ${ }^{30}$ As the dissent points out, this is vastly over-simplified. Even someone very confident about their patent knows that litigation is a risk, and for someone risk-averse, the payment may be worthwhile to avoid

25. See C. Scott Hemphill, An Aggregate Approach to Antitrust: Using New Data and Rulemaking to Preserve Drug Competition, 109 CoLUM. L. REV. 629,641 (2009) (raising the factual question of how frequently these settlements occur).

26. Id. (" $[\mathrm{H}]$ ow do we know that the payment was made in exchange for delay, rather than for some other valuable consideration?").

27. Actavis, 133 S. Ct. at 2234.

28. Id. at 2235 .

29. Id.

30. Id. at 2236 . 
the risk of an erroneous lower court finding against the patent, even if that finding was likely to be reversed on appeal. ${ }^{31}$ This raises three basic questions:

(1) How do we determine what is a "large" payment? The Court indicates merely that the scale of reverse payments should be weighed against the brand's anticipated litigation costs, the value of any services provided by the generic, and other justifications raised by the defendants. ${ }^{32}$ But are these the only factors? A reverse payment of $\$ 1$ million may seem large in the context of a product that sells $\$ 10$ million per year. But in the context of a $\$ 1$ billion product, it would not seem large at all.

(2) Do we really care if the patentee has "doubts" about the strength or survival of the patent, or is this a shorthand way of saying that such a large and unexplained payment suggests that the patent actually is invalid or not infringed? If the latter, that shorthand argument runs smack up against the facts of some of the most famous litigated cases. In the Cipro litigation, ${ }^{33}$ Bayer settled the first case with Barr; then Ranbaxy, Schein, Mylan, and Carlsbad each challenged the Cipro patent. In each case, Bayer produced the record of the Barr case. Bayer won all the subsequent cases. ${ }^{34}$ The reverse payment certainly did not reflect a weakness in the patent!

(3) What explanations will serve to justify an otherwise "large" reverse payment? The Court states that the payment may be an estimate of saved litigation expenses, or "may reflect compensation for other services that the generic has promised to perform-such as distributing the patented item or helping to develop a market for that item." 35

31. Id. at 2244-45 (Roberts, C.J., dissenting); see also Bernard \& Tom, supra note 18, at $626-27,622-23$. The importance of allowing settlement to protect against unjustified theft of the innovator's intellectual property as the result of an erroneous trial court decision seems to be ignored here.

32. Actavis, 133 S. Ct. at 2236.

33. In re Ciprofloxacin Hydrochloride Antitrust Litig., 544 F.3d 1323, 1328-29 (Fed. Cir. 2008).

34. Ranbaxy withdrew its certification and abandoned the litigation. In the Schein and Mylan cases, Bayer won on summary judgment and the Court of Appeals for the Federal Circuit affirmed. Carlsbad's challenge to the patent was rejected in a bench trial, and it did not appeal. I want to thank counsel for Bayer for providing me with this information. See also In re Ciprofloxacin, 544 F.3d at 1329 .

35. Actavis, 133 S. Ct. at 2236. 
C. Does Actavis require an inquiry into the strength of the patent at issue in evaluating a settlement? The Court recognized that if parties were forced to litigate the validity of the underlying patent to defend against antitrust challenges to patent settlement agreements, the incentive to settle would be significantly diminished. ${ }^{36}$ The Court claimed, however, that

[I]t is normally not necessary to litigate patent validity to answer the antitrust question .... An unexplained large reverse payment itself would normally suggest that the patentee has serious doubts about the patent's survival. And that fact, in turn, suggests that the payment's objective is to maintain supra-competitive prices to be shared among the patentee and the challenger rather than face what might have been a competitive market - the very anticompetitive consequence that underlies the claim of antitrust unlawfulness. ${ }^{37}$

What is meant by that "normally" is not clear. Does it mean that sometimes an "unexplained large reverse payment" does not suggest anything bad and is not illegal? Or does it mean that even if there is no payment, there can still be a violation? If the latter is true, then no settlement on any terms is safe from attack. One would hope that was not the Court's intent.

\section{DID THE COURT SLAY A BRONTOSAURUS?}

Both the majority and the dissent in Actavis focus on settlements involving cash payments from the patentee to the alleged infringer. The only problem is that such cash payments have become less and less common (even when they were held to be perfectly legal).

Scott Hemphill has done extensive research as to the facts of the reverse payment cases, and the results are instructive. ${ }^{38}$ Since 2005, the clear trend in the cases has been away from cash payments entirely. The settlements are being based on side deals, the kinds of "other services" that the Court in Actavis says may justify the "payment." 39 So, if cash deals are out of fashion, how do we evaluate whether or not there has been that "unexplained large reverse payment" that triggers scrutiny?

36. Id. at 2234,2237 .

37. Id. at 2236 (emphasis added).

38. See Hemphill, supra note 25, at 657-61. Even those of us who disagree with Scott's conclusions and prescriptions owe him a debt of thanks for his work in obtaining and laying out the underlying data.

39. See id. at 649 tbl.2; see also id. at 663-65. 


\section{QUO VADIS?}

First, when we evaluate a settlement involving services or products provided by the alleged infringer, the question cannot rationally be whether the parties would have done the deal absent the litigation. Such a test would eviscerate the Court's opinion as to legitimacy of fair value deals. If the parties had wanted to deal with each other apart from the litigation settlement context, they would have. This is simply another facet of the Court's finding that if the transaction is for fair value, then it should be allowed without regard to the pendency of the patent infringement case.

In our context, the question has to be: "Notwithstanding the litigation, does this deal represent a fair value transaction for both parties?" So, how do we determine fair value? Enter the economists and consultants. Businesses value products and services every day, and those values should be the starting point for looking at a settlement. But since the parties know that the FTC and a veritable swarm of plaintiff's lawyers will be picking the deal apart, having the imprimatur of experts with a lot of initials after their names becomes a wise investment.

Second, as we have noted earlier, any settlement agreement involves some sort of consideration to the defendant-whether in the form of foregone damages, express monetary payment, or other benefit. Settlement, after all, is a compromise-not total surrender. So does the Court's adoption of a rule of reason test in Actavis, broadly read, mean that agreements entailing any consideration-short of an agreement that simply allows the generic to enter before the underlying patent expires-must be defended by showing that the value of the consideration does not include a premium to the generic to stay out of the market? That would be to resurrect the presumption of illegality, which the Court decisively rejected. No rational company provides services without making a profit. Since there is no presumption of illegality, the burden is on the challenger to show that there is a premium and that such premium is not simply a fair profit in the transaction.

Finally, there is one really interesting potential train wreck that seems to have been overlooked in the initial analyses. The unexplained large payment (bad) and the fair value for services (good), are rational individually, but a mess when put together. 
A payment with no explanation invites argument that it was for some malign purpose; here delayed generic entry. Conversely, a payment that can be fully explained as compensating the generic for real services (say, distributing product) almost has to be legal. The alternative would be to hold that once patent litigation is filed, the two parties cannot do ordinary business together, which would be ludicrous.

This leads to the conundrum that the Court has left us. If the business deal between the patentee and the potential infringer is large enough, even if entirely defensible at fair value, the profit on the side deal could be enough to convince the generic to agree to a later entry date. But there is no "payment" for delay at all.

Yet if you condemn a legitimate side deal simply because it can generate legitimate business profits for the generic, there is no stopping point, and all settlements that are anything other than partial surrender by the patentee are illegal. Not even the FTC argued that, being content to argue that a reverse payment created a presumption of illegality, a position that the Court unanimously rejected in Actavis. ${ }^{40}$

\section{A RADICAL, YET CONSERVATIVE CLOSING THOUGHT}

The Court's decision raises many interesting topics for later discussion. But let's step back a bit first. Much of the debate over reverse payment settlements in Hatch-Waxman cases has simply assumed the inherent rightness of the current statutory structure, specifically the 180 days of generic exclusivity to the first filer. It has been an argument about what should happen at the back end, when the patent cases brought under the statute settle. But what if, instead of trying to regulate the downstream outcomes, we look to change the upstream motivations and pressures?

At the time the statute was passed, it was assumed that the first filer would litigate its case to conclusion. But that overlooked the fact that almost all patent cases settle. The

40. The dissent would have upheld the "scope of the patent" test. Actavis, 133 S. Ct. at 2238 (Roberts, C.J., dissenting). The majority ordered a full "rule of reason" inquiry. Id. (majority opinion). There were no votes for the presumption of illegality that the FTC sought. And if you cannot rely on "fair value of deal" as a complete defense, we are then thrown back on strength of the patent, which the Court did not want to get into and, one might say, implicitly rejected as unworkable. See id. at 2234 . 
intent of the 180-day exclusivity was to encourage challenges to patents and to knock out weak patents. In fact, what it has done is encourage a lot of patent challenges, even when the challenger has almost no chance of winning. ${ }^{41}$ The structure incentivizes long-shot challenges in the hopes of being boughtoff in settlement. ${ }^{42}$

The 180-day exclusivity is worth a lot more today than it was when Hatch-Waxman was passed. In 1984, generic substitution was permissible. Now it is mandatory in almost all cases. ${ }^{43}$ So why don't we make the first filer earn that reward by either pursuing the case to conclusion or settling in a way that does not block later filers? Scott Hemphill and Mark Lemley have provided an elegant analysis for making just such a change. ${ }^{44}$ As radical as it might seem at first glance, this is really a very conservative approach. Rather than trying to regulate how litigation is settled, it moves to the cause of what troubles critics of the settlements. ${ }^{45}$

With all due respect to the consultants and litigators, this may just be the way out of the swamp. If you shut off the water flow at the entrance, you don't need to keep trying to build dams to regulate the exit.

41. See Smith \& Gleklen, supra note 16 , at 6 .

42. Id.

43. Bernard \& Tom, supra note 18 , at 624 . There is always an exception for a doctor to indicate that the branded product should be dispensed, but the extra time and effort involved, and the added cost to the patient, makes this a relatively insignificant part of the market. Id. (citing a Novartis study showing that generic substitution rates were between $83.8 \%$ for commercial/group plans and $97.1 \%$ for Medicaid plans).

44. C. Scott Hemphill \& Mark A. Lemley, Earning Exclusivity: Generic Drug Incentives and the Hatch-Waxman Act, 77 ANTITRUST L.J. 947, 985-88 (2011). We do not agree with all of their prescriptions and arguments, but we do believe that the approach could work in the real world.

45. Following up on Hemphill and Lemley, there is also a need for research into the actual business models of some generics companies. The assumptions about generic drug company behavior that underlie many of the arguments in the Hatch-Waxman settlement field may well be factually incorrect. For example, Johnson \& Johnson has been involved in patent litigation for some time over a low dose oral contraceptive, Ortho Tri-Cyclen Lo. After the first challenger launched at risk (which served to trigger the 180day exclusivity for the first filer) and was enjoined (which eliminated the exclusivity entirely), Johnson \& Johnson still had to defeat seven more challengers to the patent. Since exclusivity was not involved, what did prompt these serial challenges? I am indebted to counsel at Johnson \& Johnson for the information on this litigation. 
